\title{
УДК 94(477-25):2-523
}

\section{Мар'яна Долинська,}

d. i. н., професор,

Украӥнський Католицьький Університет

e-mail:mardol@ucu.edu

\section{ПОЧАТКИ ПРОСТОРОВОЇ ЛОКАЦІЇ ЛЬВОВА В ОСТАННІЙ ТРЕТИНІ ХІІІ СТОЛІТТЯ}

Уява про просторову структуру Львова кінця ХІІІ ст. залишалася незмінною протягом останніх ста - ста n'ятдесяти років. Так само усталилося переконання, що князь Лев надав першому німецькому війту Бертольду Штехеру нерухомість у межах і поруч сучасного містечка Винники.

Однак просторовий ретроспективний аналіз показуе, що ще до надання Львову магдебурзького права Казимира III у 1356 р. існували як мінімум три об'єкти з рисами, щзо відповідали засадам просторовій локації міста на магдебурзькому праві: лан, млин та міське село. Перший з них - лан костелу Діви Марї- тягнувся між Старостинською юридикою (колишнім подолом княжого періоду) і міським селом Замарстинів, а млин Штехера розташовувався безпосередньо поруч перших двох. Аналіз низки документів дозволяє стверджувати, що міське село Замарстинів було засноване ще в останній чверті ХІІІ cm. і мало статус маєтку війта Штехера $і$, очевидно, іншу назву. Ці просторові об 'єкти, згадки про іригаційні роботи князя Лева та окремі планувальні особливості магдебурзького середмістя переконують, що в просторовому вимірі магдебурзьке право поширилося на Львів у княжу добу наприкіниі XIII cm.

${ }^{1}$ Капраль, М. (1998). Привілеї міста Львова XIV-XVIII ст. (історико-джерелознавчий огляд). Привілеї міста Львова (XIV-XVIII ст.). Збірник документів. Львів, с. 15-16; Войтович, Л. (2014). Лев Данилович, князь галицько-волинський (бл. 1225 - бл. 1301). Львів, с. 155-157. Леонтій Войтович вважає, що в цей час за нормами магдебурзького права могли жити і такі міста, як Перемишль та Володимир: там само. с. 156.
Ключові слова: лан і млин костелу святої Діви Марії, Бертольд Штехер, Замарстинів, просторовий устрій міста, пізньосередньовічний Львів

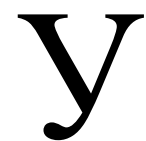

продовж останніх десятиліть з'явилися переконливі твердження про надання Львову магдебурзького (німецького) права ще в княжі часи. Більшість авторів датують цей процес останньою третиною XIII ст. за часів князя Лева Даниловича ${ }^{1}$. Аналіз просторової структури міста в ретроспекції та деяких його природно-топографічних особливостей також підтверджує вірогідність такого факту і дає змогу твердити про елементи просторової локації міста на засадах магдебурзького права вже за княжої доби.

(C) Долинська Мар'яна, 2019 
2 Долинська, М. (2006). Історична топографія Львова XIV-XIX ст. Львів, 2006. 356 с

3 Лан - одиниця площі, рівна приблизно $25 \times 104$ $\mathrm{M}^{2}$, територією, виміряною в ланах, у пізньому Середньовіччі наділялися магдебурзькі міста. У натурі це була дуже витягнута земельна ділянка довжиною біля 2300 м і шириною понад 100 м: Могитич, Р. (2003). Передмістя самоврядного Львова у першій половині XVII ст. Вісник "Укрзахідпроектреставрачї””. Ч. 13, с. 33. Первісно “лан” означав винятково одиницю площі, а в процесі формування загального міського простору поступово перетворився на термін для характеристики великого земельного наділу єдиного власника. Обшари - обмежена частина простору, переважно чимала (Słownik języka polskiego, доступний за відсиланням: http://sjp.pwn.pl/szukaj/ obszary); обшари, надані місту 1415 і 1444 pp., прилягали до території, виміряної в ланах, і не мали кількісної характеристики.

${ }^{4}$ Привілеї... с. 33-36. Док. № 3.

${ }^{5}$ Sta łanów inwentarz główny z osobna każdych verificatią, na sześć tractatów rozdzielony, в Zubyk, R. (1930). Gospodarka finansowa miasta Lwowa w latach 1624-1635, Lwów, s. 461.

${ }^{6}$ Центральний державний історичний архів України (далі - ЦДІА України у Львові. Ф. 52 (Магістрат міста Львова). Оп. 1.Спр. 108. Арк. 18 зв. («За яким Замарстиновом від узбіччя $є$ ще один лан, останній зі ста, за столановим привілеєм належний до костелу Діви Марії, власниками якого $€$ їх милості пани ксьондзи прелати»).

${ }^{7}$ Sta łanów inwentarz... s. 461.

${ }^{8}$ Привілеї...c. 35. Док. № 3.
Адміністративно-територіальний поділ магдебурзького Львова фактично не мав цілісного комплексу ознак, класичних для таких міст. Прямокутник Середмістя оточували терени двох передмість, до яких від півночі, заходу і півдня прилягали засновані в різний час села (Малехів, Замарстинів, Клепарів, Голоско Мале і Велике, Брюховичі, Скнилівок, Кульпарків, Зубря, Сихів), що належали місту - міській Раді. Окремим анклавом між Замарстиновом, Малеховом і Середмістям вклинювалася так звана Старостинська юридика королівської юрисдикції². Аналіз послідовності набуття у власність міста ланів і обшарів ${ }^{3}$, їхнє загосподарювання показує, що на тлі чіткої ланової структури передмість трапляються винятки, які можна пояснити хіба що складенням окремих просторових об'єктів раніше від інших.

Як випливає з локаційного привілею князя Володислава Опольського від $1368 \mathrm{p.}^{4}$, лани тягнулися від «чола» мурів, тобто їхні вузькі сторони були розташовані паралельно до прясел міських фортифікацій, а самі лани розходилися від них радіально, утворюючи в такий спосіб територію Галицького передмістя. Лани Краківського передмістя, Клепарова та обох Голосок охоплювали терени, які тягнулися в напрямку схід-захід, на території Замарстинова лани розташовувалися в південно-північному напрямку.

У пізніших документах, зокрема Інвентарі 100 ланів ${ }^{5}$, мабуть для полегшення обліку нерухомої власності, територія Галицького передмістя поділена на 4 тракти, які можна вважати умовними частинами цього передмістя. Кожен 3 них мав свій порядковий номер і складався 3 декількох ланів. П’ятий тракт збігався з Краківським передмістям, шостий об'єднував міські села.

І вже наприкінці цього документа (з абзацу) вписано «один останній лан». У чорновому варіанті Інвентаря: «Za którym Zamerstynowem od zboczu iest ieszcze ieden łan ze stu ostateczny z przywileiu stolonowego kościołowi P[anny] Mariey należący którego są possesormi toy M[ościowie] PP[anowie] Xięza prałaci» $^{6}$ («За тим Замарстиновом біля узбіччя $\epsilon$ ще один лан, із [усіх] ста - останній; відповідно до столанового привілею належить костелу Діви Марії, власниками якого є пани ксьондзи прелати»). У чистовому варіанті: «Po których ostaje w końcu Zamerstinowa o granicę Zboiskami na kościół Panny Marjej przywilejmi głównemi stołanowemi wyłączony i darowany z młynem tamże ostatni łan $1 »^{7}$ («Після яких залишається в кінці Замарстинова біля межі зі Збоїськами на костел Діви Марії привілеями головними столановими виключений і дарований з млином останній лан 1 »). Формулювання чистового варіанта «Головного інвентаря...» дуже нагадує перекладений з латини фрагмент тексту локаційного привілею Владислава Опольського 1368 р.: “Крім того, млин згаданого костелу святої Діви Марії, що 3 давніх часів і навічно до цього костелу приданий, разом з одним ланом, що також цьому костелові належить, до згаданих 100 ланів приєднуємо. І млин пана Григорія Штехера, львівського міщанина, в межах і розмірах (так в перекладі) вищезгаданих 100 ланів чи мансів також хочемо залишити» ${ }^{8}$. 
9 Долинська, М. Історична топографія... с. 145150.

${ }^{10}$ Sta łanów inwentarz... s. 461; Долинська, М. (2005). Неопублікований список «Головного інвентаря ста ланів...» 1608 р. для міста Львова. Наукові зошити історичного факультету Львівського наиіонального університету імені Івана Франка: Збірник наукових пращь. Вип. 7, с. 103.

${ }^{11}$ Akta Grodzkie i Ziemskie z czasów

Rzeczypospolitej Polskiej z archiwum tak zwanego Bernardyńskiego we Lwowie. (1872). T. 2. Lwów, s. 1.

${ }^{12}$ У документі 1607 р. він фігурує як млин прелатів, який називають Штехерівським, пізніше він іменувався млином каноніків, млином капітули: Долинська, М. Історична топографія... с. 218-220.

${ }^{13}$ Долинська, М. (2008). Елементи локації Львова у княжу добу. Записки Наукового товариства імені Шевченка. Т. 255: Праці комісії архітектури та містобудування, с. 78-85.

* Територія млина знаходиться на терені Лако-фарбового заводу при вул. Хімічній.

** Лан починався від стику пр. Вячеслава Чорновола $з$ вул. Хімічною, його довга сторона тягнулася вздовж цієї вулиці і вул. Жовківської до перетину вулиць Вячеслава Липинського та Богдана Хмельницького.

${ }^{14}$ Козубська, О. (2001). Львівський костел Марії Сніжної в історіографії. Наукові зошити історичного факультету Львівського начіонального університету ім. І.Франка: Збірник наукових праць. Вип. 4, с. 327-333.

\section{МІсто: ІСТОРІЯ, КУЛЬТУРА, СУСПІЛЬСТВО}

Чому документ XIV ст. окремо виділяе один єдиний зі ста ланів? Причина, найправдоподібніше, полягає в тому, що з послідовного опису ста ланів він випадав, виокремлюючись топографічно - місцем свого розташування. Як відомо, земельні надання магдебурзького міста складалися 3 величезних компактних наділів ${ }^{9}$, а лан «Діви Марії» виокремлювався в просторі, тому логічно було також і описувати його окремо, що, до речі, збереглося і в традиції пізніших фіскальних документів ${ }^{10}$. Не випадково в привілеї 1368 р. наступне речення після згадки про «останній один» лан вказує млин Г. Штехера, розташований на території 100 ланів.

Імовірний предок Григорія Бертольд Штехер був війтом німецької громади міста, i князь Лев надав йому у власність млин (та село Малий Виник) ${ }^{11}$, що засвідчує впровадження як елементів правової локації магдебурзького міста, так і просторових рис, характерних для цього права.

Млин Б. Штехера належав його спадкоємцям щонайменше до кінця XIV ст., зберігав свою назву до XVII ст. ${ }^{12}$ i проіснував на незмінному місці аж до початку XX ст. ${ }^{13}$ Попри

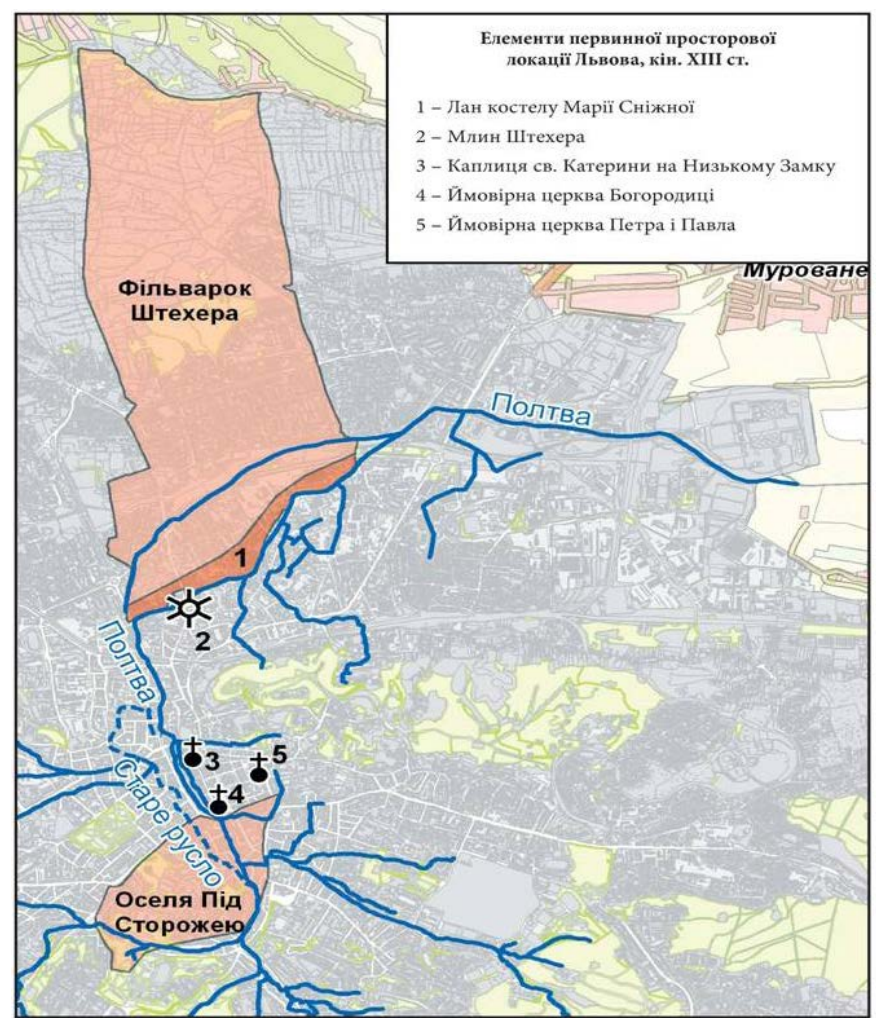

Просторові елементи магдебурзського права у Львові кінця XIII - початку XIV ст. Реконструкція Мар'яни Долинської (подано за: Атлас українських історичних міст. - Т. 1: Львів)

територію, що належала до млина*, у північно-східному напрямку тягнувся 1 лан**, виміряний i подарований костелу Марії Сніжної раніше, ніж решта земельних донацій Львова. Оскільки історіографічна традиція пов'язує побудову названого костелу з дружиною князя Лева Констанцією ${ }^{14}$, найімовірніше, і вимірювання цього лану мало відбутися за його володарювання.

Ще 2 лани неправильної форми розташовувалися далі на південь від згаданих лану і млина й мали нетипову форму, наближену до трикутника, сторони якого тягнулися від Галицької брами вздовж східних схилів Калічої гори, далі - на південь до злиття річки Свинориї і Срібного потоку 3 Полтвою, звідки - дещо східніше назад на північ до південного прясла міських фортифікацій та 
Привілей Казимира III на право власності на нерухомість нащадкам війта Бертольда Штехера від 22 серпня 1352 р. Пергамент, на шовковому червоному шнурку пошкоджена печатка. Опубл.: AGZ, t. II, стор. 1-3

Зберігається: Центральний державний історичний архів України у Львові, ф. 131, спр. 2.

${ }^{15}$ Zubyk, R. (1930). Gospodarka finansowa miasta Lwowa w latach 1624-1635. Lwów, s. 75.

${ }^{16}$ Долинська, М. Історична топографія... c. $149-150$

17 Там само. с. $157-159$.

${ }^{18}$ ЦДІА України у Львові. Л. Ф. 52. Оп. 1. Спр. 492. Арк. 102.
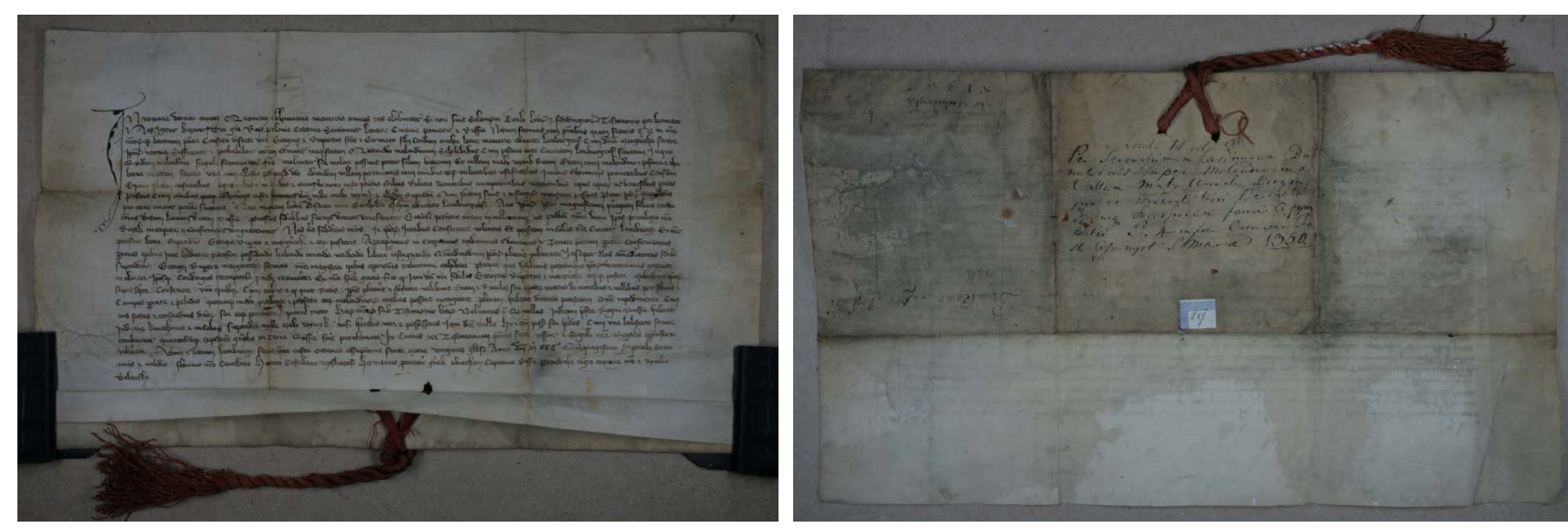

вздовж нього. У межах цих ланів знаходилася реміснича оселя «Під Сторожею». Згадка про чинші 3 неї, які почали надходити до міської каси від 1404 р. ${ }^{15}$, спонукає до гіпотези про зумовлення нетипової конфігурації ланів окремого тракту тим, що на момент першої відомої земельної донації (1356 р.) їх уже виміряли і тоді просто внесли такими, якими вони були на той час, до загального ареалу ${ }^{16}$.

Отже, перед привілеєм Казимира III 1356 р. про надання Львову магдебурзького права існували як мінімум три територіальні об'єкти з рисами, притаманними просторовій локації міста 3 магдебурзьким правом. Два з них - лан костелу Діви Марії та млин Штехера - розташовувалися поруч, а від півночі лан костелу Діви Марії межував з міським селом Замарстинів. Як уже згадано, лани цього села орієнтовані в напрямку південь-північ, тобто тягнулися перпендикулярно до ланів Краківського передмістя та решти розташованих у цій частині львівського терену міських сіл (Клепарова, Голоска Великого і Малого). Логічно припустити, що територія майбутнього села Замарстинів сформувалася дещо раніше від першої земельної донації 1356 р., коли в ареалі 70 ланів король Казимир III надав місту терени, на яких згодом сформувалися Галицьке і Краківське передмістя ${ }^{17}$. На користь цього припущення свідчить документ, складений у Замарстинові 25 січня 1605 р. - Акт опротестування [меж] між гміною Замарстинова і Львовом та вирок суддів (Akta protesty mędzy gminą Zamarstynowa a gminą $\mathrm{m}$. Lwowa i wyrok inkwizytorow ${ }^{18}$ ). Вiн розпочинається 3 твердження, що на той час використання землі склалося не на користь замарстинівського двору, а далі подано, так би мовити, коротку історичну довідку Замарстинова. Вона розпочинається з інформації про те, що Петро Штехер (Petrus Stecher) був райцею міста Львова та власником Замарстинова, так само як і його предки. У 1423 р. Штехери продали Замарстинів Янові Зомерштейну і від того часу родина 
${ }^{19}$ ЦДІА України у Львові. Л. Ф. 52. Оп. 1. Спр. 492. Арк. 109.

${ }^{20}$ Там само. - Арк. 156 зв.

Фрагмент кадастрової карти 1849 р., де межа передмістя «кутом», в якому розташований млин, вклинюється на терени села Замарстинів.

Зберігається: Центральний державний історичний архів України у Львові, ф. 186 оп. 8 , спр. 629 , арк. 7

* Прут (chorda, fenus)=7,5 ліктя, шнур як міра довжини $=10$ прутів, малий шнур=10 малих прутів=125 стіп ( 1 ст. $=0,314$ м), 1/2 курії=60 стіп $(21,3$ м $)=4$ прути.

${ }^{21}$ ЦДІА України у Львові. Ф. 52. Оп. 1.Спр. 492. Арк. 111 зв.

22 Там само. Арк. 109 зв.

23 Долинська М. Історична топографія... с. 149$150,154-155,218-221$.
Мıсто: ІстоРІЯ, КУЛЬТУРА, СУспІЛЬСТВО

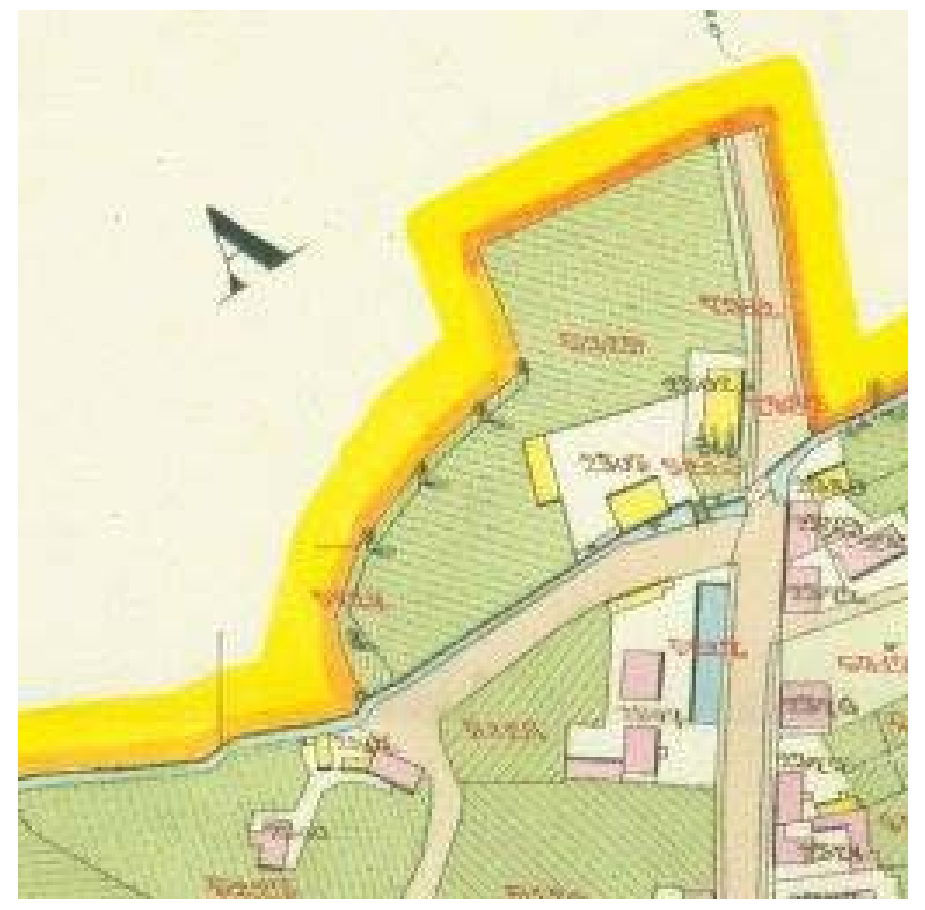

Зомерштейнів отримала прізвисько Штехер. Штехера польською мовою називали Стачора (staczora), а руською - Снадзь (snadz), бо вживані в німецькомовній грубій книзі привілеїв від 1423 р. чужі слова були важкі для вимовляння (вжитку) полякам і русі («... zathym polakom albo russi nie własnie słowa były do wymowy») ${ }^{19}$.

Інший запис того ж акта стверджує: за свого життя Ян Зомерштейн купив від Петрової Штехерової (Piotrowey Stecherowey) дев'ять прутів спадщини при млині Грегора Штехера ${ }^{20}$, які після його (Зомерштейна) смерті успадкувала Катаріна. Райці додали йому ще один прут, щоб була вільна дорога до його фільварку біля Голоска, щоб і фільварок, і гребля краще прилягали до міста. [Територію, якою володіють усі Зомерштейни] між межами Головська і Збоїськ називають фільварковою осадою і Волею, завширшки десять прутів*. До 1502 р. Замарстинів переходив до різних спадкоємців, 3 яких Петер Ліндж (Piotr Lindrz) заснував (?) Волицю і Заріччя або Поріччя (Wolica y Zarzecze albo Porzecze zasiadło). Як райці отримали на них право - не відомо, у документах щодо цього немає нічого, вони починаються лише від 1603 p. $^{21}$

Водночас в іншому місці сказано, що, як можна з’ясувати з Раєцьких книг 1599 р., у Замарстинові тягнувся лан костелу Діви Марії, виділений зі ста ланів і успадкований від монахинь (Co z Аct pp[anów]. Radziec Lwowskich... A[nno] 1599. I thu in bonis Zamerstynow 1 łan Panny Maryi rzeczony divisione centum laneorum didycowane od pp[anien]. Kośsielnych ${ }^{22}$ ).

Згадані в різних місцях прізвище Штехерів, лан костелу Діви Марії (Марії Сніжної), присілки Поріччя і Волиця, млин, що належав до Замарстинівського маєтку (млин Штехера) ${ }^{23}$, дають підстави вважати, що йдеться про первинне ядро просторової локації міста на магдебурзькому праві останньої третини XIII ст., коли князь Лев наділив німецького війта Бертольда Штехера нерухомістю (млином і місцевістю Винник). Адже всі згадані просторові елементи оточували міське село Замарстинів: лан відділяв його на півдні від Старостинської юридики (королівського Краківського 
24 Зубрицький, М. (2013). Село Мшанець Старосамбірського повіту. Матеріяли до історії Галицького села. Зібрані твори і матеріали. Т. 1. Львів, с. 297.

${ }^{25}$ Там само.

* Штучне русло Полтви (каналізоване на зламі XVIII-XIX ст.) пролягало від кінця просп. Т. Шевченка до початків просп. В. Чорновола.

${ }^{26}$ Ісаєвич, Я. (1996). «Альтана посеред раю»: Львів у 1582-1602 рр. Львів: Історичні нариси. Львів, с. 38.

27 Долинська, М. Історична топографія... с. 207-208. Для прикладу, в «Головному інвентарі... « 1608 р. Зазначено: «wdłuż iedne strone przeż Garcarskiey ulicy, gdzie on meat stary dzieli brzegami te przedmieską osade» (ЦДІА України у Львові. Ф. 52, оп. 1, спр. 108, арк 12-12зв.). Meat (від франц.) - канал.

${ }^{28}$ Атлас українських історичних міст. (2014). За наук. ред. М. Капраля. Т. 1: Львів. К., 95 с. +25 оригінальних карт, 11 карт-реконструкцій,6 видів міста. Плани і карти. 1.3. передмістя), на західній межі лану стояв млин Штехера, а далі на захід локалізовані присілки Поріччя і Волиця.

Надзвичайно цікавим $є$ документ, у якому площа Замарстинова подана не в ланах, а прутах. Ця одиниця мусила бути дуже архаїчною, адже не може мати нічого спільного з відомими в історичній метрології прутами, оскільки названі прути не є співмірними навіть з вузькою стороною лану (5,33 м - прут і понад 100 м - вузька сторона лану). Етнографічні дані кінця XIX ст. свідчать, що на той час лан мав 16 прутів або шнурів 6-ліктьових ${ }^{24}$. Крім того, при вимірюванні площі його довжина не була однаковою, а «поселенцї дбали лише про означенє ширини лану» ${ }^{25}$.

Перелічені нюанси схиляють до висновку, що якийсь Штехер (можливо, навіть Бертольд) був засновником і першим власником пізнішого Замарстинова, усталена у львівських джерелах історична назва якого походить від прізвища пізніших власників.

У такому разі вже в останній третині ХІІІ ст. склалася цілісна система просторових елементів, локованих відповідно до магдебурзького права, яка об’єднувала терен маєтку (фільварку Б. Штехера), прилеглий до нього його ж млин і 1 лан костелу Марії Сніжної.

Так само деякі просторові елементи дають змогу допускати вірогідність започаткування й забудови середмістя за княжої доби. Північна лінія оборонних мурів і паралельна до неї вулиця Вірменська не прилягають до західного і східного прясла під прямими кутами, утворюючи трапецієподібний план середмістя. Природні умови (рельєф і відсутність річок) дозволяли на цьому терені виміряти «місто в мурах» ідеального квадратного плану. Відхилення від просторових засад магдебурзького середмістя можна пояснити існуванням забудови на цьому місці перед його вимірюванням. Також на зміну конфігурації середмістя впливало штучне русло Полтви*. Мартин Груневег, німецький купець (пізніше - монах), який мешкав у Львові впродовж 1582-1602 рр., розповідаючи про часи князя Лева, стверджував: «оскільки в ті часи Полтва блукала по долині й утворювала в лісі під узгір'ям велике болото, князь розпорядився збирати воду в рів і відводити іiі, осушувати землю... А тоді князь Лев почав під своїм замком вимірювати місто.... ${ }^{26}$. Останню фразу витлумачити однозначно важко. Відсилання до старого русла Полтви фігурують у документах до XVII ст. ${ }^{27}$, а карти зберігають його зображення до кінця XVIII ст. ${ }^{28}$ Якщо князь Лев дійсно проводив меліораційні роботи, то їхньою метою могло бути не тільки осушення терену, а й використання штучного русла для оборони міста. Безпосередня близькість нового русла до середмістя і Низького замку, як і у випадку з північною лінією фортифікацій, наводить на думку, що ці терени вже освоювалися (забудовувалися) наприкінці XIII ст.

Каплиця святої Катерини на території Низького замку була чи не однією з найдавніших львівських церков, що виконувала функцію княжої замкової каплиці. Мартін Груневег вважав, що вона колись «була руською, як ще й тепер свідчить вся ії будова», згадав про гарні «мальовила єван- 
${ }^{29}$ Ісаєвич, Я. «Альтана...» С. 41.

${ }^{30}$ Chodyniecki, I. (1865) Historia stół. krol. Galicyi i Lodomeryi m. Lwowa od założenia jego aż do czasów terazniejszych w r. 1829 wydana. Wydanie wznowione. Lwów.

${ }^{31}$ Ісаєвич, Я. «Альтана...» с. 42.

\section{Мıсто: ІстоРІя, кУЛЬтУРА, сУспІльство}

гельських історій і святих, все на руський лад» ${ }^{29}$. На території середмістя за княжих часів могли бути й дві інші церкви. Ще до XVII ст. зберігалася пам'ять про те, що і на місці сучасних будівель римо-католицького кафедрального костьолу ${ }^{30}$ й монастиря домініканського ордену за часів князя Лева стояли руські церкви. Щодо останньої М. Груневег переконливо обгрунтовує, що образ (ікона) Марії «...пам'ятає початки храму; раніше він, без сумніву, був у пошані в русинів та греків» ${ }^{31}$. Якщо парафіяльні або монастирські церкви будувалися у якомусь конкретному місці, то неподалік від них мусили бути будинки міщан, а це ще раз переконує, що міська забудова існувала на теренах так званого «міста в мурах» князя Лева.

Отже, аналіз просторового розташування нерухомості родини Штехерів вказує на те, що у Львові ще в княжу добу утворилося просторове осердя магдебурзького міста, що розташовувалося на терені пізнішого міського села Замарстинів, безпосередньо поблизу княжого подолу (пізнішої Старостинської юридики). Не можна виключати, що саме в той час забудовувалося і майбутнє «місто в мурах».

\section{References}

Kapral, M. (1998). Pryvileii mista Lvova 14-18 st. (istoryko-dzhereloznavchyy ohliad), in Pryvileii mista Lvova (14-18 st.). Zbirnyk dokumentiv. Lviv.

Voytovych, L. (2014). Lev Danylovych, kniaz halytsko-volynskyy (bl. 1225 - bl. 1301). Lviv.

Dolynska, M. (2006). Istorychna topohrafiia Lvova 14-19 st. Lviv.

Mohytych, R. (2003). Peredmistia samoriadnoho Lvova u pershiy polovyni 17 st. Visnyk «Ukrzakhidproektrestavratsiia». Ch. 13.

Słownik języka polskiego, (doi: http://sjp.pwn.pl/szukaj/obszary).

Tsentralnyy derzhavnyy istorychnyy arkhiv Ukkrainy u Lvovi, (dali - TsDIA Ukkrainy u Lvovi). F. 52 (Mahistrat mista Lvova). Op. 1. Spr. 108.

Akta Grodzkie i Ziemskie z czasów Rzeczypospolitej Polskiej z archiwum tak zwanego Bernardyńskiego we Lwowie. (1872). T. 2. Lwów, s. 1.

Dolynska, M. (2005). Neopublikovanyy spysok «Holovnoho inventaria sta laniv...»

1608 r. Dlia mista Lvova. Naukovi zoshyty istorychnoho fakultetu Lvivskoho natsionalnoho universytetu im. I. Franka: Zbirnyk naukovykh prats. Vyp. 7, s. 89-105.

Dolynska, M. (2008). Elementy lokatsii Lvova u kniazhu dobu. Zapysky Naukovoho tovarystva imeni Shevchenka. T. 225: Pratsi komisii arkhitektury ta mistobuduvannia, s. 78-85.

Kozubzka, O. (2001). Lvivskyy kostel Marii Snizhnoi v istoriohrafii. Naukovi zoshyty istorychnoho fakultetu Lvivskoho natsionalnoho universytetu im. I.Franka: Zbirnyk naukovykh prats. Vyp. 4, s. 327-333.

TsDIA Ukkrainy u Lvovi). F. 52 (Mahistrat mista Lvova). Op. 1. Spr. 492.

Zubrytskyy, M. (2013). Selo Mshanets Starosambirskoho povita. Materiialy di istorii Halytskoho sela. Zibrani tvory i materialy. T. 1, Lviv. 
Isaievych, Ya. (1996). «Altana posered raiu»: Lviv u 1582-1602 rr. Lviv: Istorychni narysy. Lviv.

Atlas ukrainskykh istorychnykh mist. (2014). Za nauk. red. M. Kapralia. T. 1: Lviv. Kyiv.

Chodyniecki, I. (1865). Historia stół. krol. Galicyi i Lodomeryi m. Lwowa od założenia jego aż do czasów terazniejszych w r. 1829 wydana. Wydanie wznowione. Lwów.

\section{Maryana Dolynska}

\section{THE BEGINNINGS OF THE SPATIAL LOCATION OF LVIV IN THE LAST THIRD OF THE 13TH CENTURY}

The researches during the last 20 years have showed that there were some spatial features of Magdeburg (city) rule in that time. Primarily the structure of the town was similar to other Central or Western European towns: a castle (castrum, burg, grad, dytynets) and an extensive settlement (podil), the latter having no fortifications and being where merchants and craftsmen lived. The initial formation of the city territory based on the principles of the space location of the cities of the German law started around the 70-th years of 13 century - the times of rule of duke Lev.

No research this period the author have applied the methodology of recreating the historical topography based on retrospective comparison of the prestatictical sources and applying it to the historical maps of the period.

The primary Lviv space of the 13th century was based on the real-estate of the first Lviv «advocatus», Bertold Stecher, and the «laneus» area of Maria Snizhna Church. (Laneus - medieval measure of area, the similar term «mansus»)

The 1368 $8^{\text {th }}$ manuscript explained the German family Stecher received land from Duke Lev without being subject to any rent. This real-estate consisted of three parts; the villa (a house in the countryside); allod (the land owned and not subject to any rent); and the molendinum (mill).

After the late $19^{\text {th }}$ century comment to Latin text insisted that all of these parts of real-estate were Everyone of Lviv 's historians knows were sure these advocate Bertold Stecher's real-estate (villa Maly Vinyk, allod Podpresk and molendinum Schilzkikut) were nearby contemporary town Vynnyky and far from $13^{\text {th }}-14^{\text {th }} \mathrm{cc}$. town of Lviv and far one from another.

Using both the method of the retrospective location of real estate and systematic-criterion approach allows to made hard conclusion, that originally, the Maria Snizhna church «laneus» was near the Stecher mill and this «laneus» had divided the Duke's jurisdiction from the Stecher settlement. Villa Maly Vinyk have changed its name to "Zamarstyniv». All these real-estate parts constituted the core of the town of the Magdeburg rule.

Lviv's downtown (town within walls) has the typical Middle Age's spatial urban form, but some specific of it shows it was founded in late $13^{\text {th }}$ century

Key words: Church st. Maria «laneus» and mile, Bertold Stecher, Zamarstyniv, spatial urban form, Late Middle Ages Lviv. 